\title{
Hemocompatibility and swelling studies of poly(2-hydroxyethyl methacrylate-co-itaconic acid-co-poly(ethylene glycol) dimethacrylate) hydrogels
}

\author{
Sava N. Dobić, Jovana S. Jovašević, Marija D. Vojisavljević, Simonida Lj. Tomić \\ University of Belgrade, Faculty of Technology and Metallurgy, Belgrade, Serbia
}

\begin{abstract}
In this study a novel series of hydrogels, based on 2-hydroxyethyl methacrylate (HEMA), itaconic acid (IA) and poly(ethylene glycol) dimethacrylates (PEGDMA) (of varying molecular weight and concentration) were prepared by free radical cross-linking copolymerization. Preliminary hemocompatibility characterization of hydrogels obtained by hemolytic activity assay indicated good compatibility with blood. Preliminary biocompatibility characterization of $\mathrm{P}(\mathrm{HEMA} / \mathrm{IA} / \mathrm{PEGDMA})$ hydrogels, done by the cytotoxicity assays using the HeLa cell line revealed that the cell viability of all samples was in the range of $97-100 \%$, with no significant decrease in cell viability with the change of PEGDMA molecular weight and concentration. Swelling studies were conducted for all P(HEMA/IA/PEGDMA) samples in a physiological $\mathrm{pH}$ and temperature range and network parameters were determined. Swelling studies showed $\mathrm{pH}$ sensitive behaviour, typical for anionic hydrogels, and temperature dependent swelling. The effects of concentration of PEGDMA component on hydrogel swelling properties depend on the PEGDMA molecular weight. The samples with 550PEGDMA show different swelling capacities when 550PEGDMA content is changed, whereas for $\mathrm{P}$ (HEMA/IA/875PEGDMA) samples there was practically no difference in equilibrium degree of swelling, $q_{\mathrm{e}}$, with varying 875 PEGDMA content, which trend is the same as in the case of $q_{\mathrm{e}}$ versus $\mathrm{pH}$ dependences. It was concluded that $\mathrm{P}(\mathrm{HEMA} / \mathrm{IA} / \mathrm{PEGDMA})$ hydrogels show good potential to be used as biomedical materials.
\end{abstract}

Keywords: hydrogel; 2-hydroxyethyl methacrylate; itaconic acid; poly(ethylene glycol) dimethacrylate; hemocompatibility; $\mathrm{pH}$-sensitive and temperature dependent swelling; network parameters.

SCIENTIFIC PAPER

UDC 66.095.26:547.462.3:678-13

Hem. Ind. 65 (6) 675-685 (2011)

doi: 10.2298/HEMIND111005102D

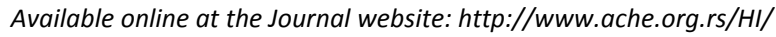

The development of new polymeric biomaterials for medical and pharmaceutical purposes is of great interest to life-care science and engineering. Hydrogels are polymeric biomaterials which do not dissolve but swell considerably in contact with aqueous and physiological media. They provide a swollen three-dimensional matrix with a predetermined amount of water or physiological fluids, resembling to some degree the environment of the native tissue [1-6]. Special types of stimuli-responsive hydrogels have been investigated for the development of "smart" materials in various fields. The term "stimuli-responsive" implies that marked changes of hydrogel volume can be induced by an external stimulus such as changes of the $\mathrm{pH}$-value, ionic strength, temperature or pressure, light, or electrical and magnetic fields [7]. For example, thermosensitive systems in aqueous media are generally aimed at changing the hydrophilic character of functional groups into a hydrophobic one, or vice versa $[1,7]$, with the

Correspondence: S.Lj. Tomić, Faculty of Technology and Metallurgy, University of Belgrade, Karnegijeva 4, Belgrade, Serbia.

E-mail: simonida@tmf.bg.ac.rs

Paper received: 5 October, 2011

Paper accepted: 5 December, 2011 change of temperature, whilst $\mathrm{pH}$ sensitive systems have basic or acid groups which react to the change of $\mathrm{pH}$ in aqueous media [1,2]. Smart hydrogels are of special interest in controlled drug release applications because of their soft tissue biocompatibility, simple loading and dispersing of the drugs in the matrix, and a high degree of control achieved by the selection of the physical and chemical properties of the polymer network and the response by volume variation to some external stimuli [5-7].

The homo- and copolymer hydrogels of 2-hydroxyethyl methacrylate (HEMA) have found extensive applications in the field of biomedicine because of their good chemical stability, high biocompatibility and physicochemical properties similar to those of living tissues $[8,9]$. Numerous studies have been conducted to modify PHEMA with the aim of improving swelling, mechanical properties and of eliciting better physiological responses to design stimuli-responsive hydrogels [10-17].

Due to the fact that IA is obtained from the non-petrochemical resources it is of a great interest for polymeric biomaterials. IA is obtained by fermentation from renewable resources such as carbohydrate mate- 
rials containing sucrose and glucose (molasses and hydrolyzed starch) [18-20].

Different properties of poly(2-hydroxyethyl methacrylate/itaconic acid) hydrogels were investigated in the last decade by few authors. Caykara et al. determined the solubility parameters of pure PHEMA and $\mathrm{P}(\mathrm{HEMA} / \mathrm{IA})$ hydrogels in 20 solvents, with various solubility parameters, in swelling experiments [21]. Tomic et al. investigated the swelling behavior and network parameters of hydrogels based on HEMA/IA and different types of poly(alkylene glycol) (meth)acrylates [22]. The same authors investigated swelling and thermodynamic properties of PHEMA and copolymeric P(HEMA/ /IA) hydrogels with varying IA content in a wide $\mathrm{pH}$ and temperature range. The copolymers showed interesting $\mathrm{pH}$ and temperature sensitivity [23]. These authors also investigated the drug release profiles from $\mathrm{P}(\mathrm{HEMA} / \mathrm{IA})$ hydrogels in order to investigate transport phenomena [24]. Metal ion adsorption on P(HEMA/IA) hydrogels was investigated for uranyl ions by Inam et al. and Ozyurek et al. $[25,26]$. Hamdy et al. studied the potential use of $\mathrm{P}(\mathrm{HEMA} / \mathrm{IA})$ hydrogels in immobilization of Citrullus vulgaris urease. Immobilized urease maintained a higher relative activity than free urease at both lower and higher $\mathrm{pH}$ levels [27]. Cytotoxicity test and hemolytic activity were investigated by Tomić et al. [28] for poly((alkylene glycol) (meth)acrylates/HEMA/ /IA) hydrogels. The in vitro study of biocompatibility showed no evidence of cell toxicity nor any considerable hemolytic activity. Also, all hydrogels showed satisfactory bioadhesive properties.

Poly(ethylene glycol) (PEG) is one of the most widely used synthetic materials for biomedical applications. Its biocompatibility, flexibility, and "stealth" properties make it ideal for use in drug delivery applications. Over the past few decades, poly(ethylene glycol) (PEG) based hydrogels have been extensively used as matrices in controlled drug delivery systems, as well as cell delivery vehicles for promoting tissue regeneration [29-32]. The versatility of the PEG macromer chemistry [33], together with its excellent biocompatibility, has spurred the development of numerous hydrogel systems for biomedical applications. Many of these studies have produced encouraging pre-clinical and clinical results.

Poly(ethylene glycol) dimethacrylate (PEGDMA), obtained by substituting PEG terminal hydroxyl groups with methacrylates, are versatile building-blocks for the preparation of "smart" biomaterials. Hydrogels containing PEGDMA crosslinker are highly tunable [34-38]. The mechanical properties of these hydrogels can be controlled by varying the molecular weight or concentration of PEGDMA. The mesh size and swelling ratio can be controlled similarly, and the mechanical and biochemical properties can be varied independent of one another.

The benefits of controlled drug delivery are essential for pharmaceutical applications as drug administration may be improved by using a delivery system designed for continuously maintaining the plasma levels of the active molecule in a therapeutically desirable range. Furthermore, drugs can be released in a precise and prolonged manner without repeated administration, thus improving patient comfort. Other benefits of controlled drug delivery are localized delivery to a particular site in the body and preservation of active agents that have short lifetimes in the body.

In this study, novel copolymeric hydrogels based on 2-hydroxyethyl methacrylate, itaconic acid (IA), and different poly(ethylene glycol) dimethacrylates (550PEGDMA and 875PEGDMA) were prepared by free radical cross-linking copolymerization. All samples were characterized via hemocompatibility and swelling studies in order to investigate the influence of molecular weight and concentration of PEGDMA on hydrogel properties.

\section{EXPERIMENTAL}

\section{Materials}

The components used in this study (Scheme 1) were 2-hydroxyethyl methacrylate (HEMA, Aldrich), itaconic acid (IA, Fluka), and poly(ethylene glycol) dimethacrylate (PEGDMA, $M_{\mathrm{n}} 550$ and 875; Aldrich). HEMA and PEGDMA components were purified by vacuum distillation before polymerization. All polymerizations were performed in water/ethanol mixture as solvent, using ethyleneglycol dimethacrylate (EGDMA, Aldrich), as cross-linking agent, potassium persulfate (KPS, Fluka), as initiator, and $N, N, N^{\prime}, N^{\prime}$-tetramethylethylene diamine (TEMED, Aldrich), as activator. Buffer solutions of different $\mathrm{pH}$ values were prepared using hydrochloric acid (La Chema), potassium chloride (Fluka), potassium mono and dihydrogenphosphate (Fluka) and sodium hydroxide (Fluka). Demineralized water was used for all polymerizations and the preparation of the buffer solutions.

\section{Synthesis of hydrogels}

The $\mathrm{P}(\mathrm{HEMA} / \mathrm{IA} / \mathrm{PEGDMA})$ copolymeric hydrogels were prepared by free radical crosslinking copolymerization. HEMA/IA copolymers were chosen because small contents of IA introduce $\mathrm{pH}$ sensitive behavior of copolymers and do not change good chemical stability, high biocompatibility and physicochemical properties similar to those of living tissues of PHEMA homopolymer. Hydrogels containing PEGDMA cross-linker are highly tunable [34-38]. The mechanical properties and the mesh size and swelling ratio can be controlled by varying the molecular weight or concentration of 
<smiles>C=C(C)C(=O)OCCO</smiles><smiles>C=C(CC(=O)O)C(=O)O</smiles>

Itaconic acid (IA)<smiles>C=C(C)C(=O)OCCOC(=O)C(=C)C</smiles>

Poly(ethylene glycol) dimethacrylates (PEGDMA) $\mathrm{n}=550 ; 875$

Scheme 1. Chemical structures of components used for hydrogel synthesis.

PEGDMA, and the mechanical and biochemical properties can be varied independent of one another.

The reactants were dissolved in water/ethanol mixture (Table 1). The PEGDMA mole fractions were 5, 10 and 15 while the HEMA/IA ratio was kept constant. The samples were designated according to monomers used and the PEGDMA molecular weight and mole fraction as $\mathrm{P}$ (HEMA/IA/550(or 875) PEGDMA-5, -10 or -15 ). The initiator, activator and crosslinker were added to the monomer feed mixture. The polymerization was carried out at $50{ }^{\circ} \mathrm{C}$ for $24 \mathrm{~h}$. The reaction mixture was degassed prior to polymerization and placed between two glass plates sealed with a rubber spacer ( $2 \mathrm{~mm}$ thick). After the reaction, the gels were cut into discs and immersed in water for a week to remove unreacted chemicals. The water was changed daily. The discs were dried to xerogels ( $1 \mathrm{~mm}$ thick and $5 \mathrm{~mm}$ in diameter). The amount of uncross-linked IA was determined by titration of extract against $\mathrm{NaOH}(0.05 \mathrm{~mol} / \mathrm{l})$ to phenolphthalein end point. On the other hand, the amount of uncrosslinked HEMA and PEGDMA were determined using a UV spectroscopy. In both cases, results indicate that the conversion during cross-linking reaction was nearly complete. The yields of $\mathrm{P}(\mathrm{HEMA} / \mathrm{IA} / \mathrm{PEGDMA})$ copolymeric hydrogels of various compositions were above $99 \%$. All the gels were transparent flexible discs with a limited fluid absorption capability.

\section{Hemolytic assay}

The hemolytic assay was determined in terms of hemolytic activity of the hydrogels by the direct and indirect contact methods, according to ISO 10 993-4 (1992) [39]. In the direct method, the hydrogel discs were immersed in $5 \mathrm{ml}$ of a physiological solution (PS) to which $0.25 \mathrm{ml}$ of whole rat blood had been added. The PS and distilled water were used as the negative and the positive control, respectively. Then the contents of the tubes were gently mixed and incubated in a water bath at $37{ }^{\circ} \mathrm{C}$ for $1 \mathrm{~h}$. Subsequently, the absorbance of the supernatant liquid in each tube was determined at $545 \mathrm{~nm}$ using a Pharmacia LKB Ultrospec Plus UV/Vis spectrophotometer and the percentage of hemolysis was calculated. The mean hemolysis value of $5 \%$ or less variation from two tests was considered acceptable. In the indirect contact method $5 \mathrm{ml}$ of an isotonic aqueous extract from a hydrogel disc was used with $0.25 \mathrm{ml}$ of a $10 \%$ suspension of rat erythrocytes. To prepare the isotonic aqueous extracts, pieces of each disc were kept for $72 \mathrm{~h}$ at $37^{\circ} \mathrm{C}$ in $100 \mathrm{ml}$ of sterilized

Table 1. Feed compositions for the P(HEMA/IA/PEGDMA) hydrogels (same conditions for 550PEGDMA and 875PEGDMA component)

\begin{tabular}{lccc}
\hline Component & P(HEMA/IA/PEGDMA-5) & P(HEMA/IA/PEGDMA-10) & P(HEMA/IA/PEGDMA-15) \\
\hline HEMA (mol\%) & 90 & 85 & 80 \\
IA (mol\%) & 5 & 5 & 5 \\
PEGDMA (mol\%) & 5 & 10 & 15 \\
initiator (mol\%) & 0.25 & 0.25 & 0.25 \\
HEMA+IA+PEGDMA (wt.\%) & 10 & 10 & 10 \\
Demineralized water (wt.\%) & 45 & 45 & 45 \\
Ethyl alcohol (wt.\%) & 45 & 45 & 45 \\
\hline
\end{tabular}


bidistilled water, and then $0.9 \mathrm{~g} \mathrm{NaCl}$ was added. The negative control was $0.9 \% \mathrm{NaCl}$ solution and $100 \%$ hemolysis was obtained in bidistilled water. After incubation at $37{ }^{\circ} \mathrm{C}$ for $24 \mathrm{~h}$, the absorbance of the supernatant was measured at $545 \mathrm{~nm}$ and the percentage of hemolysis was calculated.

\section{FTIR spectral analysis}

Xerogels were crushed into powder, mixed with potassium bromide (Merck IR spectroscopy grade) in the proportion $1: 100$, and finally dried at $40{ }^{\circ} \mathrm{C}$. The dry mixture was compressed to a $12 \mathrm{~mm}$ semi-transparent disk by applying a pressure of $65 \mathrm{kN}$ (Pressure gauge, Shimadzu) for $2 \mathrm{~min}$. FTIR spectra were recorded using a BOMEM Michelfan MB-102 FTIR spectrometer in the wavelength range $4000-700 \mathrm{~cm}^{-1}$, with a resolution of $4 \mathrm{~cm}^{-1}$.

\section{Swelling study}

Dynamic swelling measurements were performed in a wide range of physiological $\mathrm{pH}$ buffers, and in the temperature range from 25 to $55^{\circ} \mathrm{C}$. Swollen gels were removed from the swelling medium at regular intervals, dried superficially with filter paper, weighed and placed in the same bath. The measurements were continued until constant weight was reached for each sample. The amount of solution absorbed was monitored gravimetrically. The equilibrium degree of swelling, $q_{e}$, was calculated as follows:

$q_{e}=\left(m_{\mathrm{e}}-m_{0}\right) / m_{0}$

where $m_{\mathrm{e}}$ is the weight of the swollen hydrogel at equilibrium and $m_{0}$ is the weight of the xerogel $[40,41]$. All the swelling experiments were performed in triplicate.

\section{RESULTS AND DISCUSSION}

\section{Hemolytic activity}

Biocompatibility testing of polymeric biomaterials is an important step in the development of systems for biomedical applications [42]. Hemocompatibility testing is an imperative for medical devices intended for direct or indirect blood exposure. The hemocompatibility of P(HEMA/IA/PEGDMA) hydrogels was evaluated by their testing for hemolysis. In the in vitro testing conditions $\mathrm{P}$ (HEMA/IA/PEGDMA) samples in contact with blood showed a mean hemolysis value less than $1.0 \%$ in the direct contact assay, and even less than $0.5 \%$ in the indirect contact assay. According to the obtained results, these hydrogels are not considered as hemolytic (Figure 1). From our earlier investigations, it is known that incorporation of small amounts of itaconic acid in hydrogels (5 mol\%), obtained from natural renewable sources, improves the hemocompatibility of PHEMA-based biomaterial [43]. Also, PEG-based polymer
(PEGDMA) is beneficial for favorable hemocompatible behaviour [42]. In accordance with the results of hemolytic activity testing all hydrogels exerted favorable hemolytic activity. From Figures $1 \mathrm{a}$ and $1 \mathrm{~b}$ it can be seen that hydrogels with low PEGDMA content (PEGDMA-5) show lower degree of hemolysis, namely better hemocompatibility. The influence of PEGDMA content is more pronounced than the influence of PEGDMA molecular weight.

\section{Spectral characteristics of P(HEMA/IA/PEGDMA)}

FTIR spectroscopic analysis was used to illustrate the chemical structure of the hydrogels and the nature of the bonds formed. All characteristic bands present in FTIR spectra of components (HEMA, IA and PEGDMA) appear in the FTIR spectrum of the obtained hydrogel (Figure 2). The spectral characteristics of P(HEMA/IA/ /PEGDMA), presented in Figure 2, revealed the characteristic stretching vibration band of hydrogen-bonded alcohol $(\mathrm{O}-\mathrm{H})$ around $3450 \mathrm{~cm}^{-1}$, the $\mathrm{C}=\mathrm{O}$ stretching vibration of the ester group also appeared at $1730 \mathrm{~cm}^{-1}$, and an absorption band with a weak shoulder around $2950 \mathrm{~cm}^{-1}$, which correspond to the stretching of aliphatic $-\mathrm{CH}_{2}-, \mathrm{C}-\mathrm{H}$ and $-\mathrm{CH}_{3}$ groups, respectively (Figure 2). The increased peak intensity of the $\mathrm{C}=\mathrm{O}$ group at $1730 \mathrm{~cm}^{-1}$ in the spectrum of $\mathrm{P}(\mathrm{HEMA} / \mathrm{IA} /$ /550PEGDMA-15) gel was associated with the presence of the additional $\mathrm{C}=\mathrm{O}$ groups from $\mathrm{IA}$. On the other hand, several bands appeared in the fingerprint region for ethylene glycol units, originating from PEGDMA component, between 1600 and $1000 \mathrm{~cm}^{-1}$. These peaks were assigned to the $-\mathrm{CH}_{2}$ scissoring band of ethylene glycol units at $1480 \mathrm{~cm}^{-1}$ and the antisymmetric and symmetric stretching bands $(-\mathrm{O}-\mathrm{R})$ of ethylene glycol units at $1160 \mathrm{~cm}^{-1}$, respectively. Other characteristic bands represent $\mathrm{C}-\mathrm{C}$ and $\mathrm{C}-\mathrm{H}$ vibrations of $-\mathrm{CH}_{3}$ and $-\mathrm{CH}_{2}-$ groups. Therefore, the FTIR spectroscopy results confirmed the incorporation of poly(ethylene glycol) dimethacrylates and itaconic acid in hydrogel.

\section{Swelling studies}

Swelling studies were performed to investigate the influence of the hydrogel composition and external stimulus signal (change of $\mathrm{pH}$ and temperature) on the swelling properties of $\mathrm{P}(\mathrm{HEMA} / \mathrm{IA} / \mathrm{PEGDMA})$ hydrogels. The changes of $\mathrm{P}(\mathrm{HEMA} / \mathrm{IA} / \mathrm{PEGDMA})$ equilibrium swelling degrees with $\mathrm{pH}$, in a physiologically important $\mathrm{pH}$ range $(\mathrm{pH} 2.20-7.40)$ at $37^{\circ} \mathrm{C}$, and temperature, in the temperature range from 25 to $55{ }^{\circ} \mathrm{C}$, in buffer of $\mathrm{pH}$ 7.40, are presented in Figures 3 and 4.

It is evident from Figure 3 ( $a$ and $b$ ) that all hydrogels show $\mathrm{pH}$-sensitive behavior, due to IA carboxyl group which gives the hydrogel anionic character and $\mathrm{pH}$ sensitivity. The equilibrium degree of swelling, $q_{\mathrm{e}}$, versus $\mathrm{pH}$ dependences shows similar trend for all samples. At low $\mathrm{pH}$ values (lower than both $\mathrm{p} K_{\mathrm{a} 1}$ and 

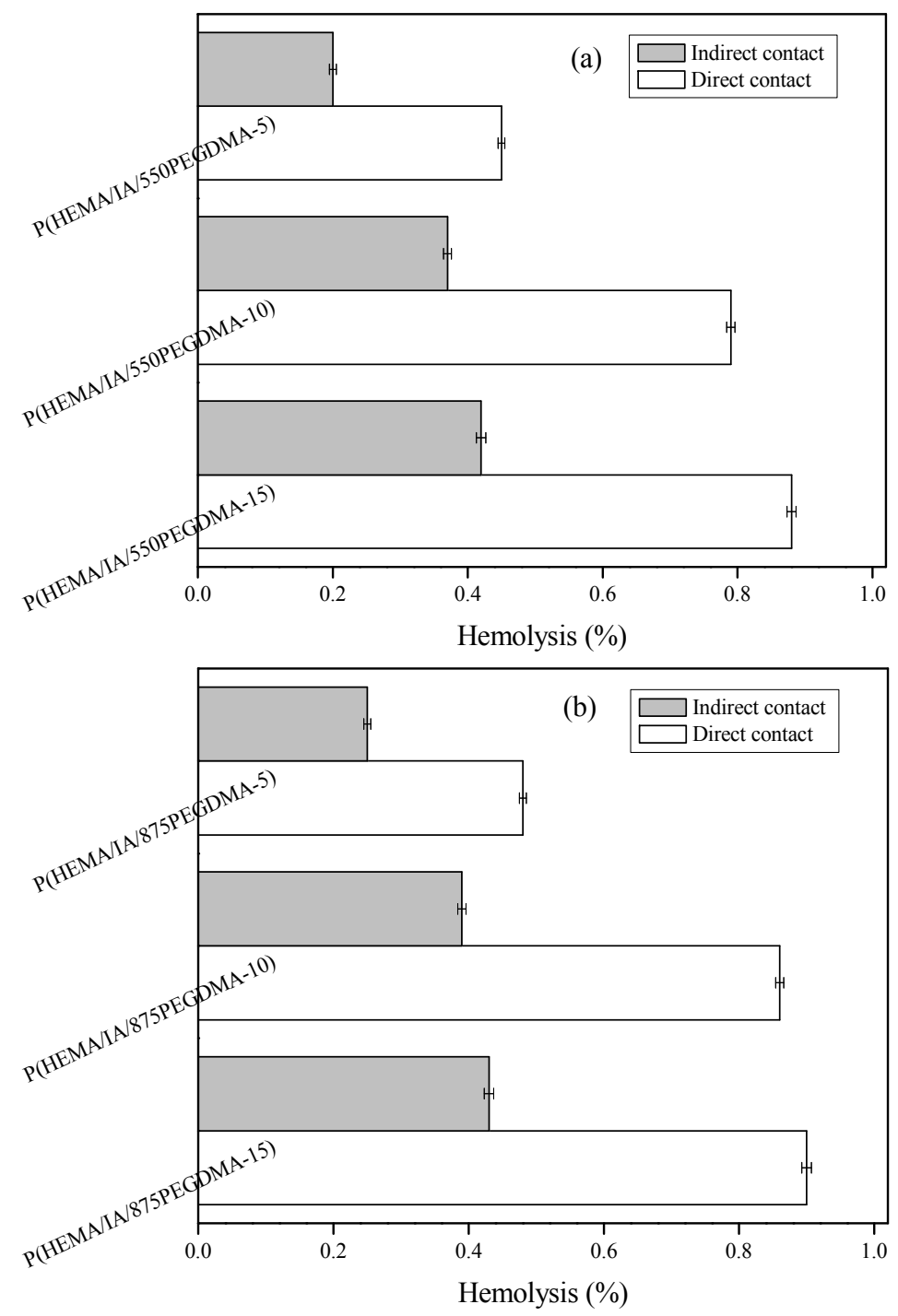

Figure 1. Hemolytic activity of $P(H E M A / I A / P E G D M A)$ hydrogels with different concentrations of 55OPEGDMA (a) and 875 PEGDMA (b).

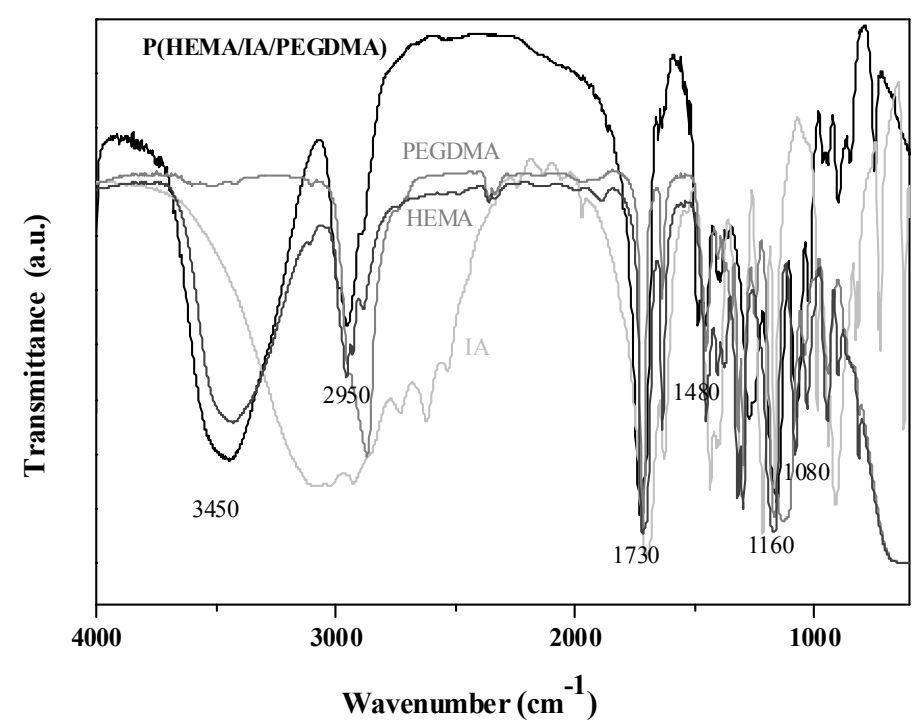

Figure 2. FTIR spectra of components: HEMA, IA, PEGDMA, and P(HEMA/IA/550PEGDMA-15) gel. 

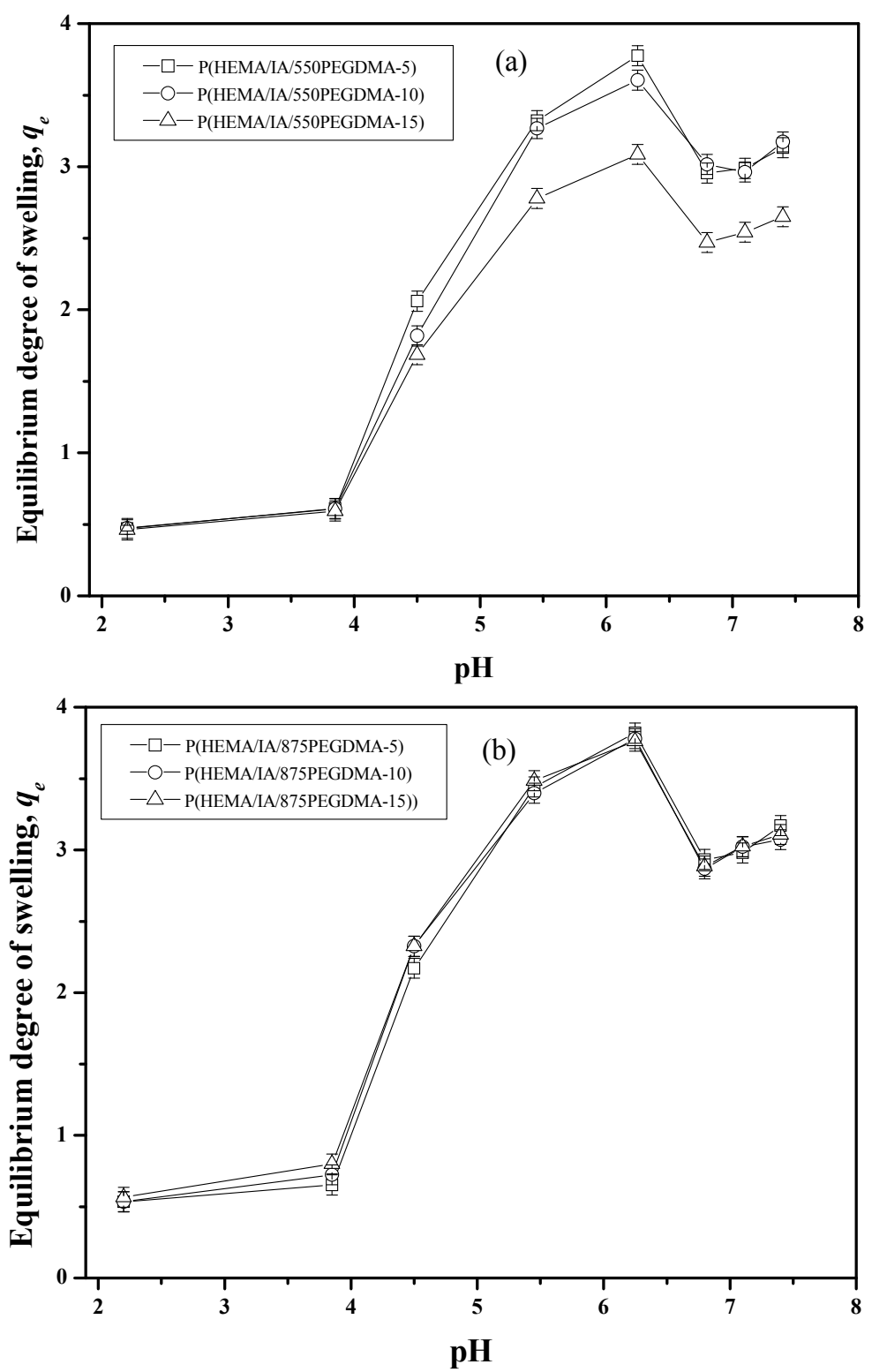

Figure 3. $p H$ sensitive swelling behaviour of P(HEMA/IA/PEGDMA) hydrogels with 550PEGDMA (a) and with 875PEGDMA (b).

$\mathrm{p} K_{\mathrm{a} 2}$ values $\left.-\mathrm{p} K_{\mathrm{a} 1}=3.85, \mathrm{p} K_{\mathrm{a} 2}=5.45\right)$, the swelling degrees are low and slightly depend on PEGDMA content, i.e., the swelling degree is low and almost similar for all the samples. The low $q_{\mathrm{e}}$ values are primary due to the intermolecular physical cross-linking, via hydrogen bond formation, between carboxylic groups in IA, as well as hydroxyl groups of HEMA, with ether groups in PEGDMA residues.

As the $\mathrm{pH}$ value of the surrounding medium rises above $\mathrm{p} K_{\mathrm{a}}$ values of both carboxyl groups, $-\mathrm{COOH}$ groups are transformed into more hydrophilic carboxylate anions, which undergo electrostatic repulsion of same charges on the network chains. Furthermore, due to ionization of $-\mathrm{COOH}$ groups the hydrogen bonds between network chains are broken and for these two reasons the swelling is substantially increased. In $\mathrm{pH}$ range above 3.85 the difference in swelling for samples with different 550PEGDMA content is more pronounced (Figure $3 a)$, i.e., the sample with highest content of 550PEGDMA (P(HEMA/IA/550PEGDMA-15) swells less than the samples $P(H E M A / I A / 550 P E G D M A-5$ and $\mathrm{P}$ (HEMA/IA/550PEGDMA-10, which is not the case with $\mathrm{P}(\mathrm{HEMA} / \mathrm{IA} / 875 \mathrm{PEGDMA}$ ) hydrogels (Figure $3 \mathrm{~b}$ ), where all samples show similar swelling properties.

The similar situation is in the case of $q_{\mathrm{e}}$ versus temperature dependences (Figures $4 a$ and $b$ ), which all show the same trend regarding the shape of the curves. It is also evident that $\mathrm{P}(\mathrm{HEMA} / \mathrm{IA} / 550 \mathrm{PEGDMA}-5)$ and $\mathrm{P}(\mathrm{HEMA} / \mathrm{IA} / 550 \mathrm{PEGDMA}-10)$ hydrogels show similar $q_{\mathrm{e}}$ values, which are higher than that for $\mathrm{P}(\mathrm{HEMA} /$ /IA/550PEGDMA-15) sample, while $q_{\mathrm{e}}$ values for P(HEMA/ /IA/875PEGDMA) do not depend much on 875PEGDMA 

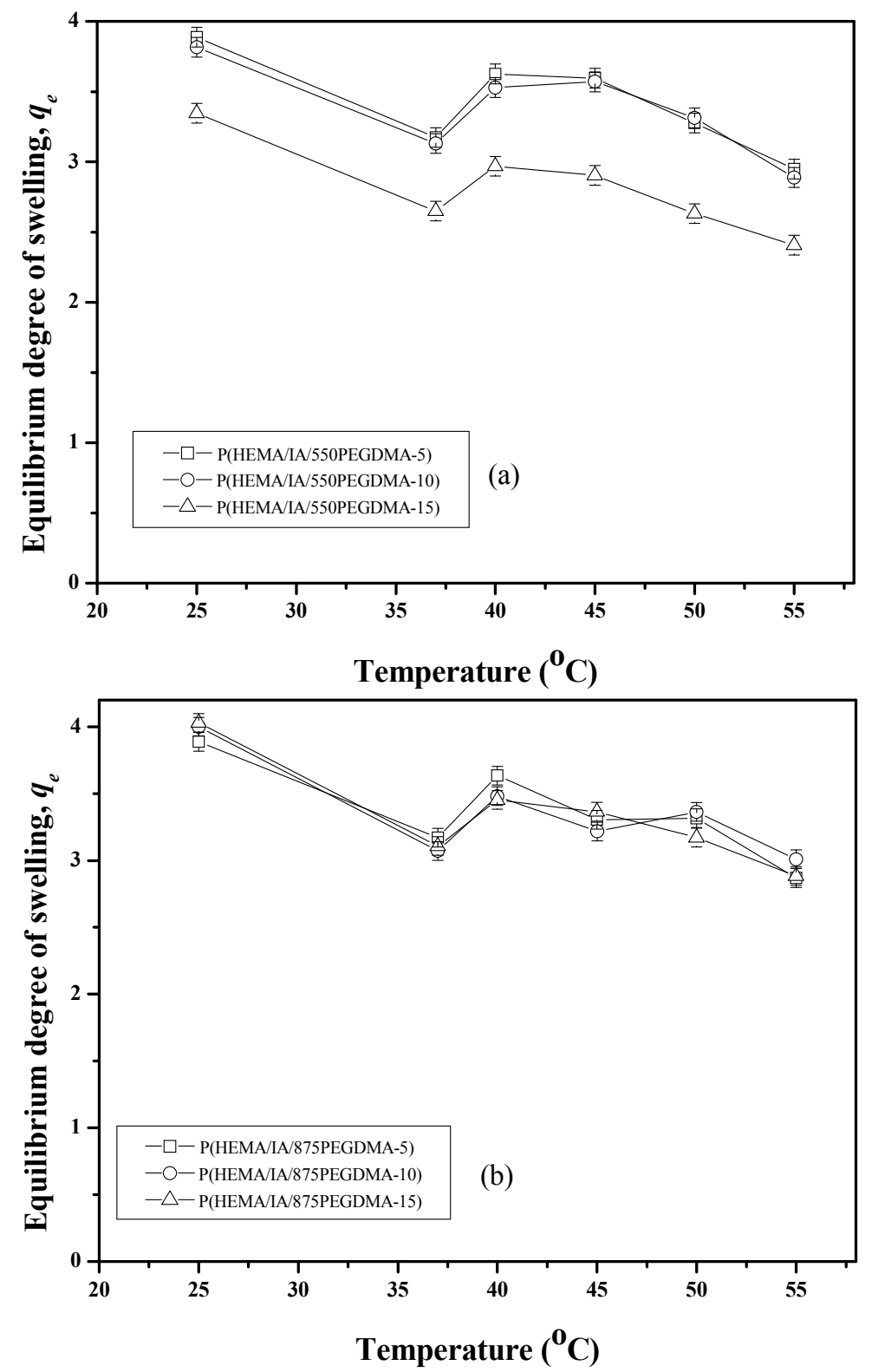

Figure 4. Temperature dependent swelling behaviour of P(HEMA/IA/PEGDMA) hydrogels with 550PEGDMA (a) and with 875PEGDMA (b).

content. In the temperature range $37-50{ }^{\circ} \mathrm{C}$ there is a small decrease in swelling with the increase of 875PEGDMA content. The P(HEMA/IA/PEGDMA) hydrogels are not temperature-sensitive, they have no LCST, but they show temperature dependent swelling. It is known that hydrogels based on HEMA homopolymer or its copolymers with IA have no LCST in the investigated temperature range $[16,44]$.

The difference in swelling capacity with the change of 550PEGDMA content can probably be explaned by the following argument. By introducing PEGDMA chains in the hydrogel structure two opposing efects take place: PEGDMA chains are hydrophilic and highly elastic, so they will induce higher swelling, but at the same time they act as a cross-linking agent, which will reduce the swelling degree. From the results obtained it is obvious that the chain length and content of PEGDMA is the main factor which determines which of those effects will prevail. This effect is clearly visible only for the samples containing 550PEGDMA because shorter 550PEGDMA chains are less flexible so there is a critical concentration (15 mol\%) where the cross-linking effect outweighs the chain flexibility effect. The longer 875PEGDMA chains are more flexible and therefore hydrogel swelling behaviour is not much influenced with 875PEGDMA contents used in this work.

Therefore, the change of environmental conditions tunes hydrogel swelling. These $\mathrm{pH}$ responsive and tem- 
perature dependent hydrogel properties along with appropriate swelling degrees values could be beneficial for their use as drug delivery systems. The $\mathrm{pH}$ responsive hydrogels play a significant role in controlled drug delivery systems [45]. These delivery systems exibit substantial changes of swelling degrees in various physiological media. Due to low swelling in acidic and higher swelling in neutral and basic media, they can protect protein drugs from denaturation in acidic media and deliver drugs in media with higher $\mathrm{pH}$ values.

\section{Network parameters}

Properties of hydrogels with weak acid moieties depend on the network structure, which is controlled by the feed composition. The most important network parameters are the molar mass of the polymer chain between two neighboring cross-linking points, $M_{c}$, the effective crosslinking density, $v_{\mathrm{e}}$, and pore size, $\xi$. In order to determine $M_{\mathrm{c}}$ for hydrogels containing diprotic itaconic acid, the following equation is used [46]:

$$
\begin{aligned}
& \frac{V_{1} X^{2} \varphi_{2 s}^{2}}{4 I \bar{V}_{\mathrm{r}}^{2}}\left(\frac{2 K_{a 1} K_{\mathrm{a} 2}+10^{-\mathrm{pH}} K_{\mathrm{a} 1}}{2\left(10^{-\mathrm{pH}}\right)^{2}+10^{-p H} K_{\mathrm{a} 1}+K_{\mathrm{a} 1} K_{\mathrm{a} 2}}\right)^{2}= \\
& =\left[\ln \left(1-\varphi_{2 \mathrm{~s}}\right)+\varphi_{2 \mathrm{~s}}+\chi \varphi_{2 \mathrm{~s}}^{2}\right]+\left(\frac{V_{1} \rho}{\bar{M}_{\mathrm{c}}}\right) \varphi_{2, \mathrm{r}}^{2 / 3} \varphi_{2, \mathrm{~s}}^{1 / 3}
\end{aligned}
$$

(3), which is described in more detail by Canal and Peppas [47]:

$\xi=\phi_{2, s}^{-1 / 3} l\left(\frac{2 C_{\mathrm{n}} \bar{M}_{\mathrm{c}}}{M_{\mathrm{r}}}\right)^{1 / 2}$

Here, $M_{r}$ is the molecular weight of the repeating unit; I the $\mathrm{C}-\mathrm{C}$ bond length $\left(1.54 \times 10^{-10} \mathrm{~m}\right.$ for vinyl polymers); and $C_{n}$, the Flory characteristic ratio, $\bar{M}_{c}$ is the average of the molar mass of repeating unit [48].

According to the potential biomedical application in dermatology and drug delivery systems, the calculations were done for the results obtained at $\mathrm{pH}$ 7.40, and $37^{\circ} \mathrm{C}$ (Table 2).

It can be seen that network parameters for P(HEMA/IA/PEGDMA) hydrogels depend on PEGDMA content in hydrogels and PEG chain length (550 and 875 ) in the similar way as in the case of $q_{e} \mathrm{vs} \mathrm{pH}$ and $q_{e}$ vs temperature dependances. The values of the molar mass of the polymer chain between two neighboring cross-linking points $\left(M_{c}\right)$ are in the range of $4715-7634$ $\mathrm{g} / \mathrm{mol}$ for P(HEMA/IA/550PEGDMA) samples and from 6392 to 8159 for $P($ HEMA/IA/875PEGDMA) samples. The pore size values of $P(H E M A / I A / 550 P E G D M A)$ and $\mathrm{P}(\mathrm{HEMA} / \mathrm{IA} / 875 \mathrm{PEGDMA})$ hydrogels are in the range of 6.7-9.5 $\mathrm{nm}$ and 6.85-9.35, respectively, i.e. they all are in the nonporous regime.

Table 2. Network parameters of P(HEMA/IA/PEGDMA) hydrogels at $\mathrm{pH}$ of 7.40 , and $37{ }^{\circ} \mathrm{C}$

\begin{tabular}{lccc}
\hline Sample & $M_{\mathrm{c}} / \mathrm{g} \mathrm{mol}^{-1}$ & $\nu_{\mathrm{e}} / \mathrm{mol} \mathrm{dm}^{-3}$ & $\xi / \mathrm{nm}$ \\
\hline P(HEMA/IA/550PEGDMA-5) & 7634 & 0.424 & 9.52 \\
P(HEMA/IA/550PEGDMA-10) & 7945 & 0.441 & 8.56 \\
P(HEMA/IA/550PEGDMA-15) & 4715 & 0.718 & 6.70 \\
P(HEMA/IA/875PEGDMA-5) & 8159 & 0.425 & 9.35 \\
P(HEMA/IA/875PEGDMA-10) & 7752 & 0.463 & 8.18 \\
P(HEMA/IA/875PEGDMA-15) & 6392 & 0.451 & 6.85 \\
\hline
\end{tabular}

where $M_{c}$ is the molar mass of the polymer chain between two neighboring crosslinking points, $K_{\mathrm{a} 1}$ and $K_{\mathrm{a} 2}$ are the first and second dissociation constants of a diprotic acid, $X$ is the weight fraction of ionizable polymer in the system, $l$ is ionic strength of the swelling medium, $\varphi_{2 s}$ is the polymer volume fraction in the swollen gel, $\varphi_{2, r}$ is the polymer volume fraction in the relaxed state, $V_{1}$ is the molar volume of water, $\rho$ is the polymer density, $\bar{V}_{\mathrm{r}}$ is the average molar volume of polymer repeating units, and $\chi$ is the Flory polymer-solvent interaction parameter. The effective crosslinking density, $v_{\mathrm{e}}$, was calculated as $v_{\mathrm{e}}=\rho / M_{\mathrm{c}}$.

The pore size, $\xi$, which is a term that describes the available space for solute transport within the polymer network, is also an important paramater in analyzing crosslinked polymers and calculated according to Eq.

\section{CONCLUSION}

Free-radical crosslinking/copolymerization of 2-hydroxyethyl methacrylate with IA and PEGDMA, with varying molecular weight and content, resulted in the formation of cross-linked P(HEMA/IA/PEGDMA) hydrogels. The aim of our study was to demonstrate the influence of poly(ethylene glycol) chain length and content on the properties of $\mathrm{P}(\mathrm{HEMA} / \mathrm{IA} / \mathrm{PEGDMA})$ hydrogels. All hydrogels show a fair level of blood compatibility, as confirmed by in vitro experiments of percentage hemolysis, and can be described as hydrogels with beneficial hemocompatible behaviour. Swelling studies showed typical $\mathrm{pH}$-sensitive swelling behaviour of anionic hydrogels, as well as the temperature dependent swelling. Itaconic acid is responsible for $\mathrm{pH}$ sensitive behavior and short, flexible poly(ethylene glycol) dimethacrylate 
chains inside the network play a role of elastic springs but at the same time act as crosslinking agent. The swelling of $\mathrm{P}(\mathrm{HEMA} / \mathrm{IA} / 550 \mathrm{PEGDMA})$ hydrogels, monitored as a function of $\mathrm{pH}$ and temperature, is influenced by the content of 550PEGDMA component. By introducing lower concentration of 550PEGDMA component in the network the hydrogel swelling increases. It can be concluded that for the samples containing shorter 550PEGDMA chains there is a critical concentration of 15 mol\% where the cross-linking effect outweighs the chain flexibility effect so they swell less than those with lower 550PEGDMA content (5 and 10 mol\%). In contrast, $\mathrm{P}(\mathrm{HEMA} / \mathrm{IA} / 875 \mathrm{PEGDMA})$ hydrogels show very small change in swelling with the change of 875PEGDMA content. The longer 875PEGDMA chains are more flexible and the crosslinking effect is balanced with the chain flexibility effect, so the swelling behavior is similar for all samples in the concentration range used in this study. The obtained results indicate that $\mathrm{pH}-$ responsive and temperature dependent P(HEMA/IA/PEGDMA) hydrogels show good potential for biomedical applications.

\section{Acknowledgement}

This work has been supported by the Ministry of Education and Science of the Republic of Serbia (grant No. 172062).

\section{REFERENCES}

[1] B.D. Ratner, D. Hoffman, F.J. Schoen and J. E. Lemons, Biomaterial Science; An Introduction to Materials in Medicine, $2^{\text {nd }}$ ed., Elsevier Academic Press, San Diego, CA, 2004, pp.115-127

[2] J. Kopecek, J. Yang, Hydrogels as smart materials, Polym. Int. 56 (2007) 1078-1098

[3] S. Chaterji, I.K. Kwon, K. Park, Smart polymeric gels: Redefining the limits of biomedical devices, Prog. Polym. Sci. 32 (2007) 1083-1122

[4] M.W. Urban, Stratification, stimuli-responsiveness, selfhealing, and signaling in polymer networks, Prog. Polym. Sci. 34 (2009) 679-687

[5] N.A. Peppas, Y. Huang, M. Torres-Lugo, J.H.Ward, J. Zhang, Physicochemical foundation and structural design of hydrogels in medicine and biology, Annu. Rev. Biomed. Eng. 2 (2000) 9-29

[6] A. Kumar, A. Srivastava, I.Y. Galaev, B. Mattiasson, Smart polymers: Physical forms and bioengineering applications, Prog. Polym. Sci. 32 (2007) 1205-1237

[7] D. Schmaljohann, Thermo- and $\mathrm{pH}$-responsive polymers in drug delivery, Adv. Drug. Deliv. Rev. 58 (2006) 1655$-1670$

[8] S. Brahim, D. Narinesingh, A.G. Elie, Synthesis and hydration properties of $\mathrm{pH}$-sensitive $\mathrm{p}(\mathrm{HEMA})$-based hydrogels containing 3-(trimethoxysilyl)propyl methacrylate, Biomacromolecules 4 (2003) 497-503
[9] S. Lahooti, M.V. Sefton, Microencapsulation of Normal and Transfected $L 929$ Fibroblasts in a HEMA-MMA Copolymer, Tissue Eng. 6 (2000) 139-149

[10] C.D. Young, J.-R. Wu, T.-L. Tsou, High-strength, ultra-thin and fiber-reinforced pHEMA artificial skin, Biomaterials 19 (1998) 1745-1752

[11] C.S. Brazel, N.A. Peppas, Mechanisms of solute and drug transport in relaxing swellable hydrophilic glassy polymers, Polymer 40 (1999) 3383-3398

[12] M.T. am Ende, N.A. Peppas, Transport of ionizable drugs and proteins in crosslinked PAA and P(AA-CO-HEMA) hydrogels. I. Polymer Characterization, J. Appl. Polym. Sci. 59 (1996) 673-684

[13] M.T. am Ende, N.A. Peppas, Transport of lonizable Drugs and Proteins in Crosslinked Poly(acrylic acid) and Poly(acrylic acid-co-2-hydroxyethyl methacrylate) Hydrogels. II. Diffusion and Release Studies, J. Control. Release 48 (1997) 47-56

[14] S.Lj. Tomić, E.H. Suljovrujić, J.M. Filipović, Biocompatible and bioadhesive hydrogels based on 2-hydroxyethyl methacrylate, monofunctional poly(alkylene glycol)s and itaconic acid, Polym. Bull. 57 (2006) 691-702

[15] S.Lj. Tomić, M.M. Mićić, J.M. Filipović, E.H. Suljovrujić, Swelling and drug release behavior of poly(2-hydroxyethyl methacrylate/itaconic acid) copolymeric hydrogels obtained by gamma irradiation, Radiat. Phys.Chem. 76 (2007) 801-810

[16] S.Lj. Tomić, M.M. Mićić, S.N. Dobić, J.M. Filipović, E.H. Suljovrujić, Smart poly(2-hydroxyethylmethacrylate/itaconicacid)hydrogels for biomedical application, Radiat. Phys. Chem. 79 (2010) 643-649

[17] I.O. Barcellos, A.T.N. Pires, I. Katime, Physical properties of hydrogels of poly(2-hydroxyethyl methacrylate) and copolymers with mono-methyl itaconate synthesized by bulk and solution polymerization, Polym. Int. 49 (2000) 825-830

[18] K. Kirimura, T. Sato, N. Nakanishi, M. Terada, S. Usami, Breeding ofstarchutilizing and itaconic-acid-producing koji molds by interspecific protoplast fusion between Aspergillus terreus and Aspergillus usamii, Appl. Microbiol. Biotechnol. 47 (1997) 127-131

[19] M. Petruccioli, V. Pulci, F. Federici, Itaconic acid production by Aspergillus terreus on raw starchy materials, Lett. Appl. Microbiol. 28 (1999) 309-312

[20] T.H. Willke, K.D. Vorlop, Biotechnological production of itaconic acid, Appl. Microbiol. Biotechnol. 56 (2001) 289-295

[21] T. Caykara, C. Ozyurek, O. Kantoglu, O. Guven, Influence of gel composition on the solubility parameter of poly(2-hydroxyethyl methacrylate-itaconic acid) hydrogels, J. Polym. Sci. Pol. Phys. 40 (2002) 1995-2003

[22] S.Lj. Tomić, M.M. Mićić, J.M. Filipović, E.H. Suljovrujić, Hydrogels based on 2-hydroxyethyl methacrylate obtained by gamma irradiation, Mater. Sci. Forum 494 (2005) 199-204

[23] M.M. Mićić, S.Lj. Tomić, J.M. Filipović, E.H. Suljovrujić, Release and diffusion studies of hydrogels based on itaconic acid, Mater. Sci. Forum 555 (2007) 441-446 
[24] S.Lj. Tomić, M.M. Mićić, J.M. Filipović, E.H. Suljovrujić, Swelling and drug release behavior of poly(2-hydroxyethyl methacrylate/itaconic acid) copolymeric hydrogels obtained by gamma irradiation, Radiat. Phys. Chem. 76 (2007) 801-810

[25] R. Inam, T. Caykara, C. Ozyurek, Polarographic determination of uranyl ion adsorption on poly(2-hydroxyethyl methacrylate/itaconic acid) hydrogels, Sep. Sci. Technol. 36 (2001) 1451-1461.

[26] C. Ozyurek, T. Caykara, R. Inam, Enhancement of uranyl ion uptake by the prestructuring of poly(2-hydroxyethyl methacrylate itaconic acid) hydrogels in the presence of lead and cadmium ions/polarographic determination, J. Appl. Polym. Sci. 90 (2003) 2385-2390

[27] S.M. Hamdy, S. El-Sigeny, M.F. Abou Taleb, Immobilization of urease on (HEMA/IA) hydrogel prepared by gamma radiation, J. Macromol. Sci., A 45 (2008) 982-989

[28] S.Lj. Tomić, E.H. Suljovrujić, J.M. Filipović, Biocompatible and bioadhesive hydrogels based on 2- hydroxyethyl methacrylate, monofunctional poly(alkylene glycol)s and itaconic acid, Polym. Bull. 57 (2006) 691-702

[29] C.C. Lin, K.S. Anseth, PEG Hydrogels for the Controlled Release of Biomolecules in Regenerative Medicine, Pharm. Res. 26 (2009) 631-643

[30] J.L. Drury, D.J. Mooney, Hydrogels for tissue engineering: scaffold design variables and applications, Biomaterials 24 (2003) 4337-4351

[31] M.B. Mellott, K. Searcy, M.V. Pishko, Release of protein from highly cross-linked hydrogels from poly(ethylene glycol) diacrylate fabricated by UV pilymerization, Biomaterials 22 (2001) 929-941

[32] N.A. Peppas, K.B. Keys, M. Torres-Lugo, A.M. Lowman, Poly(etylene glycol) containing hydrogels in drug delivery, J. Control. Release 62 (1999) 81-87

[33] C.R. Nuttelman, M.A. Rice, A.E. Rydholm, C.N. Salinas, D.N. Shah, K.S. Anseth, Macromolecular Monomers for the Synthesis of Hydrogel Niches and Their Application in Cell Encapsulation and Tissue Engineering, Prog. Polym. Sci. 33 (2008) 167-179

[34] M.A. Al-Nasassrah, F. Podczeck, J.M. Newton, The effect of an increase in chain length on the mechanical properties of polyethylene glycols, Eur. J. Pharm. Biopharm. 46 (1998) 31-38
[35] J.W. Gunn, S.D. Turner, B.K. Mann, Adhesive and mechanical properties of hydrogels influence neurite extension, J. Biomed. Mater. Res., A 72 (2005) 91-97

[36] N.C. Padmavathi, P.R. Chatterji, Structural characterization and swelling behavior of poly (ethylene glycol) diacrylate hydrogels, Macromolecules 29 (1996) 1976$-1979$

[37] S.R. Peyton, C.B. Raub, V.P. Keschrumrus, A.J. Putnam, The use of poly(ethylene glycol) hydrogels to investigate the impact of ECM chemistry and mechanics on smooth muscle cells, Biomaterials 27 (2006) 4881-4893

[38] S. Nemir, H.N. Hayenga, J.L. West, PEGDA hydrogels with patterned elasticity: Novel tools for the study of cell response to substrate rigidity, Biotechnol. Bioeng. 105 (2010) 636-644

[39] ISO document 10 993-4: Biological evaluation of medical devices. Part 4, 1992

[40] C.L. Bell, N.A. Peppas, Measurement of the swelling force in ionic polymer networks. III. Swelling force of interpolymer complexes, J. Control. Release 37 (1995) 277-280

[41] N.A. Peppas, Analysis of Fickian and non-Fickian drug release from polymers, Pharm. Acta Helv. 60 (1985) 110-111

[42] J.B. Park, R.S. Lakes, Biomaterials, ch. Tissue Response to Implants, Springer, 2007, pp. 266-288

[43] S.Lj. Tomić, S.I. Dimitrijević, A.D. Marinković, S. Najman, J.M. Filipović, Synthesis and characterization of poly(2-hydroxyethyl methacrylate/itaconic acid) copolymeric hydrogels, Polym. Bull. 63 (2009) 837-851

[44] S. Tomić, unpublished results.

[45] N.A. Peppas, Hydrogels and drug delivery, Curr. Opin. Colloid In. 2 (1997) 531-537

[46] T. Caykara, M. Dogmus, O. Kantoglu, Network Structure and Swelling-Shrinking Behaviours of $\mathrm{pH}$-Sensitive Poly(acrylamide-co-itaconic acid) Hydrogels, J. Polym. Sci.: Pol. Phys. 42 (2004) 2586-2594

[47] T. Canal, N.A. Peppas, Correlation between Mesh Size and Equilibrium Degree of Swelling of Polymeric Networks, J. Biomed. Mater. Res. 23 (1989) 1183-1193

[48] L.F. Gudeman, N.A. Peppas, pH-sensitive membranes from poly(vinyl alcohol)/poly(acrylic acid) interpenetrating networks, J. Membrane. Sci. 107 (1995) 239-248. 


\section{IZVOD}

\section{PROUČAVANJE HEMOKOMPATIBILNOSTI I BUBRENJA HIDROGELOVA POLI(2-HIDROKSIETIL METAKRILAT-KO- -ITAKONSKA KISELINA-KO-POLI(ETILEN GLIKOL) DIMETAKRILAT)}

Sava N. Dobić, Jovana S. Jovašević, Marija D. Vojisavljević, Simonida Lj. Tomić

Univerzitet u Beogradu, Tehnološko-metalurški fakultet, Beograd, Srbija

(Naučni rad)

$\mathrm{U}$ radu je izvedena sinteza dva nova tipa kopolimernih hidrogelova na bazi 2-hidroksietil (met)akrilata, itakonske kiseline i poli(etilen glikol) dimetakrilata, s ciljem primene ovih polimernih sistema u biomedicinske svrhe. Testirana je biokompatibilnost preko probe hemokompatibilnosti. Hemolitička aktivnost svih hidrogelova je bila u dozvoljenim granicama, prihvatljivim za biomedicinsku primenu. Studije bubrenja hidrogelova, izvedene u opsegu fizioloških $\mathrm{pH}$ i temperaturnih vrednosti, pokazale su da bubrenje zavisi od pH i temperature. Sintetisani hidrogelovi su pokazali sličan trend zavisnosti stepena bubrenja od $\mathrm{pH}$ i temperature. Sadržaj 550PEGDMA u hidrogelu utiče na stepen bubrenja, dok koncentracija 875PEGDMA komponente vrlo malo utiče na stepen bubrenja. Hidrogel sa 15 mol\% 550PEGDMA manje bubri od uzoraka sa manjim sadržajem ove komponente (5 i 10 mol\%), što ukazuje da pri toj koncentraciji preovladava umrežavajuće dejstvo ove komponente. Duži PEG lanci u 875PEGDMA su fleksibilniji, pa je efekat umrežavanja uravnotežen sa efektom fleksibilnosti lanca, što ima za posledicu slično bubrenje za sve uzorke u opsegu koncentracija koje su korišćene u ovom radu.

Ključne reči: 2-Hidroksietil metakrilat • Itakonska kiselina • Poli(etilen glikol) dimetakrilat • Hidrogelovi • Hemokompatibilnost • pH-Osetljivo i temperaturno zavisno bubrenje $\bullet$ Parametri mreže 